\title{
Viden er vækst
}

\section{Studiekredsene og bibliotekerne 1910-1930}

\author{
Af Bodil Holt Kjar
}

\section{Indledning}

Formålet med denne artikel er at belyse studiekredsbevægelsens opståen, udbredelse og organisation i Danmark i perioden 1910-1930, samt at undersøge arten og omfanget af samarbejdet mellem studiekredsene og bibliotekerne, to væsentlige faktorer i dansk folkeoplysning, som har haft det fælles mål at gøre læsning, arbejde med bøger, til et effektivt middel i folkeoplysningens tjeneste.

Tidsafgrænsningen er begrundet $\mathrm{i}$, at de første famlende forsøg på at organisere de fa spredte studiekredse her i landet fandt sted 1910-11. Der er lagt vægt på at skildre Studiekredsforeningens virksomhed 1918-29 ret indgående, fordi jeg mener, at dens indsats generelt er blevet undervurderet. Ofte omtales den blot med et par mere eller mindre nøjagtige sætninger. Ganske vist fik studiekredsarbejdet først det store opsving med AOF, men dette ville næppe have været muligt, hvis ikke Studiekredsforeningen gennem sin agitationsvirksomhed og sin udgivelse af studievejledninger havde beredt en gunstig grobund for arbejdet.

Kulturhistorisk baggrund for studiekredsbevagelsen og bibliotekerne Dansk folkeoplysning har sine rødder tilbage i 1700-tallets oplysningstid, men blev først lovhjemlet ved skoleloven af 1814. Ifølge en bestemmelse heri skulle der tilbydes undervisning for den konfirmerede 
ungdom i by som på land to gange ugentligt, én for piger og én for karle, i de elementære undervisningsfag.

Af mange praktiske grunde blev lovens intentioner kun i ringe grad ført ud i livet. Forældre og arbejdsgivere havde ofte ikke megen forståelse for nytten af unge menneskers skolegang, og den nye lov lagde øget beslag på lærernes kræfter i børneskolen. Undervisningen af de unge blev pålagt lærerne som en ekstra, vederlagsfri embedspligt, hvilket nok heller ikke har virket befordrende for motivationen. Dette blev der først rådet bod på med et cirkulære i 1846, som opfordrede skolekommissionerne til at lønne lærerne for ungdomsundervisningen.

Skoleloven af 1814 kom også til at betyde en vis opblomstring af de almuebiblioteker, som siden oplysningstiden havde set dagens lys og eksisteret i kortere eller længere tid under yderst usikre vilkår, men først da bibliotekerne i 1882-83 fik tilskud på finansloven, begyndte der at tegne sig et sikrere billede af deres rolle i samfundet.

De spæde tilløb til en ungdomsundervisning fik først for alvor vind i sejlene, da Grundtvigs og Kolds skoletanker omkring århundredets midte førte til oprettelsen af folkehøjskolerne. Hånd i hånd med de folkelige bevægelsers krav om større politisk frihed, som opnåedes med grundlovens indførelse, gik et øget behov for en folkelig oplysning. Højskolerne kom til at indtage en meget central plads i dansk folkeoplysning og indgik i levende vekselvirkning med de øvrige folkelige bevægelser i sidste halvdel af 1800-årene. Især efter nederlaget i 1864 kom der stærk vækst i oprettelsen af højskoler, som skulle blive kraftfelter i en national og moralsk genopbyggelse. Hvad udad tabtes, skulle indad vindes.

Arbejderstanden, som først manifesterede sig senere med den stigende industrialisering fra 1870 'erne, kunne af politiske og andre grunde derimod ikke bruge de traditionelle højskoler i sin frigørelsesproces. De grundtvigske højskoler med deres national-poetiske, evangeliskkristelige budskab vandt ringe genklang $i$ arbejderbevægelsen med dens internationale indstilling og afvisende holdning over for kirken. Den frembrydende arbejderbevægelse tog de aftenskoler og ungdomsskoler i brug, som sideløbende med højskolerne omsider var vokset frem.

Højskolens fremmeste undervisningsmiddel var det frie, mundtlige foredrag med betoning af en karakterdannende oplysning snarere end 
af en egentlig kundskabsmeddelelse. Selvom højskolen var imod 'bogterperi', fik den dog indirekte indflydelse på, at der igen kom liv i de hensygnende bogsamlinger. På enkeltpersoners initiativ oprettedes der nye biblioteker, men først ved biblioteksloven af 1920 fik disse mere fast grund under fødderne.

I 1900-årenes andet årti begyndte man i folkeoplysningsinteresserede kredse, især blandt bibliotekssagens forkæmpere, lærere og i den progressive fløj af højskolebevægelsen at arbejde for en større forståelse af bøgers og læsnings betydning for det videre folkeoplysende arbejde.

Det naturlige mål for dette arbejde var at sætte den enkelte samfundsborger i stand til at øve større indflydelse på arbejdspladsen og $\mathrm{i}$ offentlige institutioner og derved indtage sin naturlige plads i et demokratisk samfund med dets rettigheder og pligter. Men det var også en praktisk dygtiggørelse til at honorere de krav, som samfundsudviklingen, herunder især den voksende industrialisering, stillede.

Den klassiske, grundtvigske hævdelse af 'det levende ord' over for 'det døde bogstav', som i øvrigt nok havde været fortolket langt ud over, hvad Grundtvig havde tænkt sig, blev debatteret og modificeret. I talrige indlæg i tidsskrifter som Bogsamlingsbladet, Folkeskolen og Højskolebladet slås der til lyd for, at foredraget ikke er nok, hvis det ikke fører til et videre arbejde med det meddelte stof. Foredrag alene bliver let til blot og bar underholdning og overfladisk 'falsk dannelse'. Det mundtlige foredrag har haft - og har - sin store mission i at 'vække folket', men nu er tiden inde til at gå et skridt videre på folkeoplysningens vej: "Vort folk har lært at høre, nu maa det ogsaa lære at læse", lyder et karakteristisk udsagn fra denne nye opfattelse. ${ }^{1}$ Fra passiv lytten til aktivt 'selvarbejde' med bøgerne, og gerne et selvarbejde i samarbejde, blev det nye ideal for folkeoplysningen. Hermed var skabt behovet for studiekredse og biblioteker, og vel at mærke biblioteker, som ikke blot skulle skaffe sine lånere en underholdende bog til en ledig stund, men som skulle udfylde en rolle som oplysende kulturfaktor.

\section{Studiekredsideens oprindelse}

Studiekredsideen kendte man fra Englands Home Reading Unions med tilknytning til de offentlige biblioteker, og især fra Sverige hvor af- 
holdsorganisationen International Order of Good Templars (IOGT) med stor entusiasme havde arbejdet med 'studiecirkler' siden århundredeskiftet. Dansk biblioteksbevægelses store pioner Andreas Schack Steenberg omtaler allerede år 1900, vist nok som den første herhjemme, denne form for oplysningsarbejde, som han har stiftet bekendtskab med i England. ${ }^{2}$

\section{Hjemmeloesningsforeningen}

Et første forsøg på at danne en fælles organisation for studiekredsarbejde her i landet blev gjort i 1910-11. Initiativtageren var højskolelærer ved Sorø Højskole, cand. theol. C. Ludvigsen. Han var stærkt engageret i bogsamlingssagen og havde på et studieophold i Uppsala stiftet bekendtskab med studiecirkelarbejdet i Sverige.

Ved et møde i Ârhus den 28. oktober 1910 om hjemmelæsningsarbejdet deltog leder af Statens Bogsamlingskomité professor Andreas Schack Steenberg, overbibliotekar Vilhelm Grundtvig og underbibliotekar Thomas Døssing fra Statsbiblioteket, repræsentanter for ungdomsarbejdet i KFUM, de socialistiske ungdomsklubber og de grundtvigske ungdomsforeninger samt repræsentanterne for Danmarks Folkebogsamlinger Johs. Grønborg og Jens Bjerre. Her indledte C. Ludvigsen om læsekredsarbejdet, udkastede mange idéer til udvikling af denne oplysningsform og foreslog, at der dannedes et udvalg, som skulle arbejde til fremme for sagen. Det skulle være centralorgan i nært samarbejde med Statens Bogsamlingskomité, hvilket faldt ganske i tråd med Steenbergs ønske. Også overbibliotekar Grundtvig gav tilsagn om Statsbibliotekets fulde støtte til sagen.

Efter en "timelang interessant Forhandling" nedsattes Udvalget for Hjemmelæsning bestående af Steenberg, Døssing, skomager Jens Madsen (for de socialistiske ungdomsklubber), cand. Witt (for KFUM) og med C. Ludvigsen som formand. Alle havde de kendskab til studiekredsarbejdet, enten fra udlandet eller i de spredte kredse, der arbejdede i Danmark inden for organisationer som Indre Mission og de socialistiske ungdomsklubber.

På et opfølgende møde 19. februar 1911 vedtog udvalget et arbejdsprogram, ${ }^{3}$ bestående $\mathrm{i}$ at: 
- tilvejebringe oplysninger om hjemmelæsningsarbejdet hjemme og ude;

- gennem Bogsamlingsbladet o.a. organer gøre rede for forskellige typer af læsekredse og derved tilskynde til dannelse af sådanne;

- tilvejebringe emneoversigter, udarbejde boglister ordnet efter sværhedsgrader og tilrettelægge læseplaner;

- evt. være behjælpelig ved valg af bøger til foreningernes læsetasker;

- tilskynde til udgivelse af savnede (=egnede) bøger;

- bede Statens Bogsamlingskomité om at virke som central for arbejdet og at hjælpe med anskaffelse af bogsæt og besørge udlån heraf.

Der er af gode grunde intet punkt om et samarbejde med folkebogsamlingerne, da disse endnu befandt sig på et stade, hvor de ville have haft meget svært ved at opfylde en folkeoplysende opgave i nævneværdigt omfang. Det blev om denne folkebogsamlingerne/ bibliotekernes rolle som folkeoplysningsinstitution, at et par årtiers kulturkamp kom til at bølge mellem de gamle bogsamlingsfolk og den nye biblioteksbevægelses talsmænd, anført af Døssing.

C. Ludvigsen skrev et par indlæg om hjemmelæsning ${ }^{4}$ og rejste i 1911 til London for at studere Home Reading arbejdet, men meget mere blev det ikke til. Af flere grunde løb dette første forsøg på at organisere studiekredsarbejdet i Danmark ud i sandet. Af personmæssige årsager, idet Ludvigsen fik et nyt:job, som beslaglagde hans tid og kræfter, og Steenberg og Døssing havde hænderne fulde med at arbejde for udviklingen og omformningen af bibliotekerne i disse år. Desuden kom der en Verdenskrig $i$ vejen, hvilket Steenberg gentagne gange angiver som en medvirkende årsag.

Et af de få synlige resultater af Hjemmelæsningsforeningens arbejde var, at Statsbiblioteket i Ârhus fik tilladelse til at udlåne vandrebogsamlinger til studiekredse på samme vilkår som til folkebogsamlinger.

I krigsårene findes der dog spor af overvejelser om en organisation af folkeoplysningsarbejdet, hvori studiekredse indgår som et væsentligt led. I 1915 udkastede bibliotekar A. Bjerregaard-Jensen således en detaljeret plan til, hvorledes man burde etablere et samarbejde mellem vigtige bestående oplysningsinstitutioner som Folkeuniversitetsforenin- 
gen, Udvalget for Folkeoplysnings Fremme og folkebogsamlingerne, som hidtil havde virket hver for sig. Arbejdet skulle fremme forståelsen af bøgers brug og nytte og derved fremskynde organisationen af folkebibliotekerne, som i Bjerregaard-Jensens plan indtog en helt central position. ${ }^{5}$

Også Th. Døssing opfordrede i 1915 til at tage studiekredstanken op igen. Han beskrev denne nye og grundige oplysningsforms betydning. Oplysningsarbejdet skal tage fat, hvor skolen slap: "Vi, der arbejder med Bogen som Oplysningsmiddel, nærer ingen Tvivl om, at den Tid vil komme, da en af Hovedopgaverne i Skolen, Folkeskolen og Efterskolen, bliver at lære Eleverne selvstændig benyttelse af Bøger. Nu er Forholdet ofte det, at Skolen vækker en Trang til Oplysning, som Eleverne senere i Livet ikke forstaar at tilfredsstille paa en fornuftig Maade og som derfor tabes igen. Her kan Studiekredse i deres forskellige Former gøre meget godt. Folkebogsamlingerne kan faa en vigtig Opgave, ikke mindst de smaa Bogsamlinger paa Landet, hvis Ledere i en sjælden Grad kan kende de Interesser, der er oppe i Egnen."

Døssing påpeger behovet for et grundbogsmateriale, en opgave, som Udvalget for Folkeoplysnings Fremme naturligt burde løse, og foreslår, at foredragsvirksomheden med stor fordel kunne kombineres med studiekredsarbejde.

\section{Studiekredsforeningen}

I 1918 tages tanken om at organisere studiekredsarbejdet op igen med fornyet kraft. Den 7. januar danner 'en kreds af interesserede' Studiekredsforeningen med professor A. S. Steenberg som formand og højskolelærer A. Olsen Thyregaard, Kærehave Husmandsskole, som sekretær. Steenberg tillægger Thyregaard æren for at have taget initiativet til genoptagelsen af arbejdet for studiekredsbevægelsen.7 Thyregaard har, som Ludvigsen før han, hentet inspiration i Sverige, hvor GoodTemplarne har organiseret studiecirkler siden 1902, og hvor Arbetarnes Bildningsförbund siden 1912 har haft en studiekredsvirksomhed i stærk vækst.

I Studiekredsforeningens 17 medlemmer store bestyrelse var repræsenteret foreninger og organisationer med interesse for oplysningsarbejde: De politiske ungdomsforeninger, De danske Ungdomsforenin- 
ger, afholdsforeningerne, De danske Købstæders Aftenskoleforbund, Dansk Biblioteksforening, de offentlige biblioteker, Det sociale Sekretariat, Folkeuniversitetsforeningen, Det kgl. Danske Landhusholdningsselskab, Husmandsforeningerne, Dansk Kvindesamfund m.fl. Th. Døssing blev formand for foreningens Arbejdsudvalg. Også en anden af bibliotekssagens store pionerer Jørgen Banke var med i bestyrelsen.

Foreningen fik fra sin start et talerør i Bogens Verden, hvis første årgang, 1918-19, blev udgivet i fællesskab mellem Dansk Biblioteksforening og Studiekredsforeningen, redigeret af Døssing under medvirken af $\mathrm{A}$. Olsen Thyregaard.

I forordet til første nummer understreges naturligheden af et samarbejde mellem bibliotekerne og studiekredsene: "Alsidigt udrustede Folkebiblioteker med kyndig Vejledning er en nødvendig Baggrund for Studiekredsarbejdet, og Studiekredsene vil kunne skaffe Bibliotekerne de bedste Læsere, dem, der stiller de største Krav, og som derfor er Bibliotekerne mest kærkomne." Bibliotekerne og studiekredsene har et fælles mål i at vejlede læserne i bøgers brug, som er "Hovedhjørnestenen i ethvert grundigt Arbejde for selvstændig tilegnet Oplysning". ${ }^{8}$

I samme nummer skriver Steenberg om Studiekredsforeningen og dens målsætning, efter først at have taget endnu et livtag med den gamle opfattelse, at bøger kun er til underholdning, men foredrag er til oplysning. Denne anskuelse er dog nu ved at fortrænges af en "Bevægelse til Fremme af det skrevne Ords Plads i Oplysningsarbejdet", hvilket har givet sig udslag dels i den stærke vækst af de offentlige biblioteker, dels i dannelsen af Studiekredsforeningen. ${ }^{9}$

Allerede i 1918 udgav Studiekredsforeningen sin første selvstændige publikation Folkeoplysning gennem Samlesning og Selvstudium. Dette lille skrift indledes med nogle generelle betragtninger over studiekredsideen, dens udenlandske forbilleder og de vanskeligheder, som arbejdet i Danmark står over for. Dernæst gives en detaljeret beskrivelse af, hvorledes en studiekreds kan tilrettelægge arbejdet med et konkret emne: Den jyske hede og Det danske Hedeselskab, delt op over 10 mødeaftener, og med angivelse af hvad der læses til hver gang. Studievejledningen med fyldige kommentarer hertil er gengivet. Der rådgives om antal deltagere, udpeg- 
ning af studieleder og dennes rolle samt valg af fælles grundbog for alle deltagere.

I et afsnit om Studiekredsforeningen opstilles dennes formål: "at virke for almen Oplysning gennem Arbejde i Studiekredse, dels inden for Fagforeninger og Institutioner, dels i private Kredse" ved:

- Udarbejdelse af studievejledninger, som vil blive offentliggjort i tidsskrift.

- Udgivelse af grundbøger og anden litteratur, der er egnet for studiekredse.

- Samarbejde med de offentlige biblioteker. Foreningen vil søge at opnå en ordning, hvorved de offentlige biblioteker, i første række folkebibliotekerne, bliver i stand til at skaffe studiekredsene den nødvendige litteratur.

- Vejledning til selve arbejdet i studiekredsene ved afholdelse af instruktionskursus for studieledere.

- Agitation for studiekredsarbejdet, dels ved foredrag, dels ved artikler i dagspressen og i tidsskrifter.

- Samarbejde med den bestående foredragsvirksomhed, således at der forud for studiekredsens arbejde afholdes et eller flere foredrag over det emne, kredsen skal behandle. Eventuelt kan emnet også uddybes eller særlige spørgsmål fremdrages i foredrag, efter at kredsens arbejde er sluttet.

Bemærkelsesværdigt $\mathrm{i}$ forbindelse med emnet for denne artikel er punkt 3: Man regner nu med folkebibliotekerne som en nødvendig og selvfølgelig samarbejdspartner, hvilket er en følge af den udvikling, som folkebibliotekerne har gennemgået siden Hjemmelæsningsforeningens programsætning i 1910-11. Der hersker en optimistisk forventning om, at der nu er skabt politisk grobund for store fremskridt for folkebiblioteksvæsenet, hvilket har udmøntet sig i markante stigninger både i de stedlige og især $\mathrm{i}$ de statslige tilskud. ${ }^{10}$ Der er tale om "en gennemgribende Reorganisation" af bibliotekerne, som har sat sig nye mål. De angelsaksiske biblioteksideer er ved at slå igennem på dansk grund. Folkebibliotekerne er en "selvstændig Faktor i Oplysningsarbejdet, sideordnet med Skolen i dens forskellige Former", ${ }^{11}$ og det må betragtes som naturligt, at den befolkning, som i skolerne har lært at læse, $i$ 
bibliotekerne får adgang til at nære og udvikle sine åndelige eller rent praktisk-materielle interesser.

\section{Studiekredsen som arbejdsform}

Studiekredsforeningens første opgave blev at oplyse om, hvad en studiekreds er, og hvorledes den arbejder. En studiekreds består af en lille gruppe mennesker, som efter en fælles metodisk plan sammen søger at tilegne sig viden om et bestemt emne ved alles aktive deltagelse. Det optimale antal deltagere vil være 5-15, den nedre grænse for at sikre tilstrækkelig gensidig inspiration, den øvre af hensyn til at alle deltagere skal have mulighed for at komme til orde i den diskussion, som ideelt danner afslutning og er hovedindhold på hver mødeaften. På et forberedende møde aftales mødehyppighed og -længde.Typisk vil man holde møder af to timers varighed hver eller hver anden uge, 10-15 gange $\mathrm{i}$ løbet af en vinter. Kredsen vælger af sin midte en studieleder, som tilvejebringer en studievejledning, efter hvilken arbejdet fordeles på samtlige deltagere. Den bør være meget detaljeret og er vigtig for, at kredsen kan få udbytte af sit arbejde. Det er også studielederens opgave at fremskaffe den supplerende litteratur og at lede kredsens diskussioner.

Studiekredsens vigtigste arbejdsredskab er grundbogen, som bør indeholde en nogenlunde fyldig beskrivelse af det valgte emne. Den bør være inddelt $\mathrm{i}$ afsnit passende til én mødeaftens gennemgang. Grundbogen bør anskaffes af alle deltagere. Før hver mødeaften forventes alle deltagere at have forberedt sig $\mathrm{i}$ det aftalte afsnit $\mathrm{i}$ grundbogen. Studielederen eller en af ham udpeget indleder vil endvidere redegøre for indholdet af det supplerende materiale $i$ et indlæg af ca. en halv times varighed. Aftenen afsluttes med diskussion af det gennemgåede, med studielederen som ordstyrer.

Således vil arbejdet i den typiske studiekreds foregå, men i øvrigt dyrkes studiekredsarbejdet i mange afskygninger. Der kan arbejdes i enkeltbogskredse eller $\mathrm{i}$ emnekredse, fra den enklest tænkelige form som en højtlæsning med efterfølgende samtale, til den højt kvalificerede kreds, som arbejder på et langt mere ambitiøst niveau.

I løbet af Studiekredsforeningens levetid (1918-1929) advares der i flere indlæg i foreningens tidsskrift mod at lægge studiekredsarbejdet op i for 
højt et plan. Studievejledningerne må ikke blive for 'vidtløftige', for akademiske for almindelige deltageres forudsætninger. Dette afspejler sig også i en diskussion i tidsskriftet Lasning om selve betegnelsen studiekreds, som efter nogles mening let kan virke afskrækkende på :jævne mennesker. Der foreslås forskellige andre navne som samlæsning og kredslæsning.

Steenberg går ind $\mathrm{i}$ diskussionen og afviser, at ordet studiekreds skulle være udslag af nogen 'titelsyge', men alene skyldes, at man har været inspireret af det svenske 'studiecirkel'. Han finder det beklageligt, hvis selve ordet skulle "afskrække Folk fra at benytte den gode Form, som Studiekredsen er til at faa det mest mulige ud af en Bog eller faa et Emne grundigt behandlet gennem Læsning", men konkluderer, at "i $\varnothing$ jeblikket forekommer det mig ikke, at der er Anledning til at forandre Centralorganisationens [i. e. Studiekredsforeningens] Navn". ${ }^{12}$

Men Steenberg er ivrig talsmand for, at studiekredsarbejdet skal være differentieret; der må arbejdes både med lettere emner på et enkelt grundlag og med sværere opgaver for viderekomne. I praksis vil det sige, at man også bør benytte enkeltbogskredse, og at der bør udarbejdes studievejledninger af langt mindre omfattende karakter.

\section{Studiekredsforeningens virksomhed}

Udgivelse af tidsskrift

Hovednerven i Studiekredsforeningens arbejde var dens tidsskrift, hvorigennem de øvrige arbejdsopgaver kanaliseredes. For en forening som denne, hvor medlemmerne ikke, som i lokale foreninger, kunne komme sammen til drøftelse af foreningens mål og midler, var et fælles medlemsblad et meget vigtigt forum for forslag, erfaringsudveksling og debat i foreningsarbejdet.

Som omtalt var foreningens første tidsskrift, Bogens Verden, fællesorgan for Studiekredsforeningen og Dansk Biblioteksforening 1918 juni 1919. Da Dansk Biblioteksforening og foreningen Danmarks Folkebogsamlinger trods mange uoverensstemmelser i september 1919 sluttedes sammen under navnet Danmarks Biblioteksforening, blev Bogens Verden denne nye forenings tidsskrift, men Studiekredsforeningen fik et samarbejde $i$ stand mod at yde et tilskud til udgivelsen, således at bladet gav spalteplads til meddelelser fra Studiekredsforeningen. 
I en kort redegørelse for dette samarbejde pointerer Studiekredsforeningens sekretær A. Thyregaard endnu engang det gensidige afhængighedsforhold mellem de offentlige biblioteker og studiekredsarbejdet, et ledemotiv gennem hele foreningens virke. ${ }^{13}$

I Bogens Verden offentliggjordes indlæg om foreningen, dens formål og aktiviteter til opfyldelse heraf, udveksling af praktiske erfaringer med studiekredsarbejde, udblik til det langt mere udviklede studiekredsarbejde i Sverige, hvortil foreningen havde tæet personlig kontakt, meddelelser om instruktørkursus for studiekredsledere o. lign. Bladet bragte også nye studievejledninger og boglister samt liste over allerede udgivne studievejledninger.

På Studiekredsforeningens årsmøde i oktober 1921 blev der imidlertid fremsat ønske om et eget tidsskrift fra flere medlemmer, som mente, at et sådant ville fremme foreningens formål bedre end meddelelser fra foreningen optaget i Bogens Verden.

Fra begyndelsen af 1922 udkom derfor foreningens eget tidsskrift Lxesning. Det udkom under snævre økonomiske rammer, men kom ikke til at koste foreningen meget mere end kontrakten med Bogens Verden havde gjort. Foreningens formand A.S. Steenberg tilbød at redigere bladet vederlagsfrit, og med beundringsværdig flid helligede han sig denne opgave i sit otium, skønt han et par år før havde set sig nødsaget til at trække sig tilbage fra biblioteksarbejdet som følge af "en aarelang Nervesvækkelse, fremkaldt af Overanstrengelse". ${ }^{14}$

De første to årgange udkom under beskedne former og med begrænset plads. Det erklærede mål var at "fremme Læsningen, som den drives i Studiekredse og af Enkeltmand. Derfor vil det give Fremstillinger af Læsemetoder og af Former for Studiekredsarbejdet. Det vil offentliggøre Studievejledninger og Boglister og, forsaavidt Pladsen tillader det, Anmeldelser af nye Bøger. I et Afsnit "Hvad skal jeg læse?" vil det bringe Udtalelser om, hvad andre har anset det værd at læse. [...] Det vil forklare, hvorledes man kan skaffe sig Bøger gennem de offentlige Biblioteker. Det vil berette om, hvad der udføres af organiseret Arbejde (gennem Studiekredsforeningen, Studiekredse o. lgn.) for at fremme Læsningen. Det vil ogsaa søge Hjælp til Arbejdet herhjemme hos vore Nabolande, af hvilke særligt Sverige har en meget omfattende 
og statsunderstøttet Organisation af Studiekredse." Således skriver Steenberg i bladets første artikel..$^{15}$

Tidsskriftet udkom i perioden 1922-1928, de to første årgange med 5 numre årligt, ca. 80 sider pr. år, som udsendtes gratis til foreningens medlemmer. Indholdet er meget varieret: artikler om studiekredsarbejdet $\mathrm{i}$ ind- og udland, foreningsmeddelelser, foreningens årsberetninger og årsregnskaber, samarbejde med andre institutioner og nogle fầ studievejledninger.

Her i tidsskriftets indledende fase er indholdet koncentreret mere om studiekredsarbejdets form end om dets indhold. Der er mange begyndelsesvanskeligheder at overvinde, bl.a. var det meget svært for foreningen at skaffe sig oplysninger om studiekredsarbejdet ude i landet, og Lxosning opfordrer gentagne gange studiekredsene til at give meddelelse om deres virksomhed, hjemsted, emne, antal deltagere og varighed.

Steenberg afslutter begge de første årgange med et lille hjertesuk over, at det er så vanskeligt at finde bidragydere til bladet, at han selv må fylde en fjerdedel af det.

I 1924 skiftede tidsskriftet karakter med hensyn til både indhold og omfang. På foreningens årsmøde i 1923 fremkom der forslag om en væsentlig udvidelse bestående af indledende artikler om spørgsmål, som var egnede til behandling i studiekredse, ledsaget af en studievejledning hertil, større emne-boganmeldelser samt anmeldelser af egnede grundbøger. Man er nået så langt i det agiterende oplysningsarbejde om studiekredsen som arbejdsform, at man nu kan lægge mere vægt på arbejdets indhold.

Steenberg kunne ikke påtage sig redaktionsarbejdet af det stærkt udvidede tidsskrift alene, men indgik i et tremands redaktionsudvalg, som også arbejdede gratis. I det hele taget fremgår det af kildematerialet, at det kun var takket være den meget store portion idealisme og ildhu hos nogle ganske få enkeltpersoner, at det lykkedes at få stablet dette store arbejde på benene.

Laesning udkommer i 1924 og 1925 med 7 numre pr. årgang med ca. 180 sider årligt, i 1926-1928 stadig med 7 numre årligt, men et faldende omfang. Hver årgang er forsynet med register. 


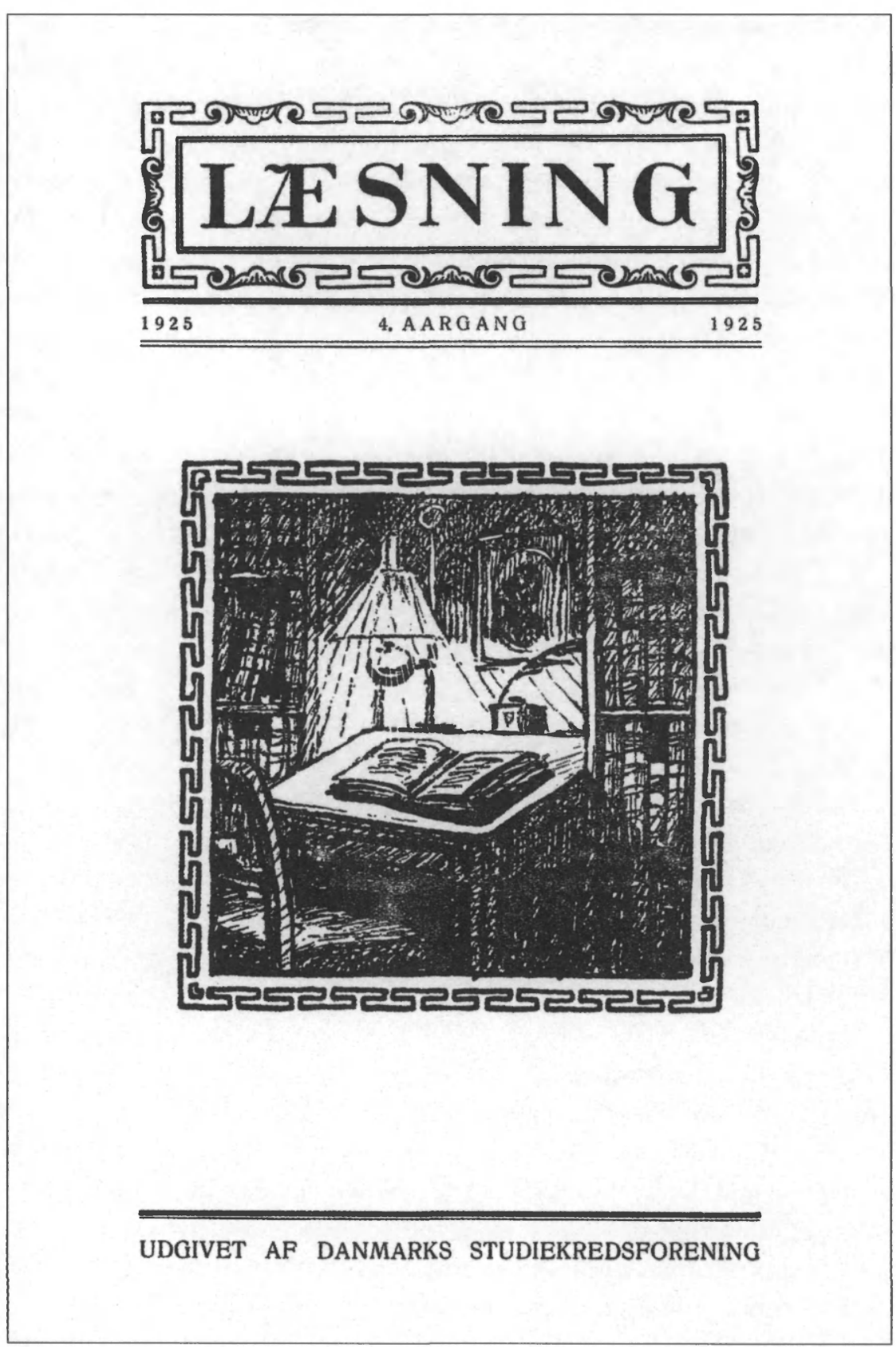

Bladet LASNING, udgivet af Danmarks Studiekredsforening, udkom 1922-1928 
Udgivelse af studievejledninger

En meget vigtig side af foreningens virksomhed er udgivelsen af studievejledninger, som er et absolut nødvendigt arbejdsredskab for studiekredsen. Som oftest vil foreningen have modtaget anmodning fra studiekredse om vejledninger i bestemte emner, hvorefter foreningen opfordrer en i det givne emne sagkyndig person til at udarbejde vejledningen. I enkelte tilfælde er vejledningerne udformede som boglister, eventuelt med kommentar, men som regel er der lagt et stort arbejde $\mathrm{i}$ at udarbejde en detaljeret vejledning, som afsnit for afsnit gennemgår den relevante litteratur til et emne. Studiekredsforeningen betaler honorar til dem, der har udarbejdet vejledningen, som sælges til interessenter for et beskedent beløb gennem foreningens sekretariat. De fleste studievejledninger bliver dog offentliggjort i Bogens Verden og Lasning, som medlemmerne modtager gratis.

I løbet af sine første ti år udgav foreningen i alt 96 studievejledninger spændende lige fra "Bælgplantedyrkning" til "Psykisk Forskning". I emnegrupper fordeler de sig efter hyppighed som følger: ${ }^{16}$

Sociale emner 28

Litterære emner $\quad 18$

Historiske emner 13

Naturhistoriske emner $\quad 12$

Praktiske fag 9

Biografiske emner $\quad 8$

Geografiske emner $\quad 3$

Religiøse emner 3

Filosofiske emner 2

\section{Øvrig publikationsvirksomhed}

Som et led i sin agitation for studiekredsarbejdet udgav foreningen allerede i sit første år det nævnte skrift Folkeoplysning gennem Samlasning og Selvstudium. Det blev udgivet i 2000 eksemplarer, blev hurtigt udsolgt og afløstes af den langt mere omfattende Studiehåndbogen (1919, 107 s.) som foruden studievejledninger indeholdt instruktive artikler af fremtrædende folk i Studiekredsforeningen, A.Thyregaard, Th. Døssing, Jørgen Banke m.fl. Af andre skrifter til hjælp for studiekredsarbejdet udkom i 1923 Vejledning i studiearbejdet af C.L. Skjoldbo og i 1926 Vej- 
ledning i Biblioteksbenyttelse og Studiekredsarbejdet (Publikum og Bibliotekerne) af bibliotekar E. Bremerstent og sekretær C.L. Skjoldbo. Der er også, især af foreningens formand A.S. Steenberg, skrevet en del artikler til landets blade for at agitere for studiekredsarbejdet.

Fra 1925 kunne foreningens skrifter og studievejledninger foruden gennem foreningens sekretariat fås gennem enhver boghandel, idet Ejnar Harcks Bogforlag tog foreningens publikationer i kommission.

En alvorlig hæmsko for arbejdet var mangelen på egnede grundbøger. Foreningen satte sig som mål at virke for udgivelsen af sådanne. Foreningen havde ikke de fornødne ressourcer til selv at forestå udgivelsen af grundbøger, men blev ved velvilje fra forskellige forlags side sat i stand til at udgive nogle få stykker. Foreningens arbejde på dette felt gik i højere grad ud på at overbevise andre institutioner, f.eks. Udvalget for Folkeoplysnings Fremme og Det kgl. Danske Landhusholdningsselskab, om det ønskelige $\mathrm{i}$ at der fremkom grundbøger $\mathrm{i}$ større antal. Foreningen arbejdede også for dette ved at medvirke i Udvalget for social Litteratur og i et samarbejde med Studentersamfundets Oplysningsforening.

Kursus- og modevirksomhed

Efter at artikler i pressen havde vakt interesse for studiekredsarbejdet, indbød Studiekredsforeningen på opfordring til sit første møde for studiekredsinteresserede på Fyns Stifts Husmandsskole den 1. og 2. oktober 1919. Der mødte 42 deltagere, fortrinsvis unge fra hele landet, af forskellige politiske og religiøse retninger. Foreningen bekostede kursus og ophold for 20 af deltagerne. Kurset blev ledet af foreningens næstformand, da Steenberg var syg. Lærere var Døssing, Banke, Thyregaard og Skjoldbo.

Der blev holdt tre foredrag om studiekredsarbejde med efterfølgende spørgetime. En konkret studievejledning blev gennemgået, og der blev undervist i bøgers brug. Endvidere blev der holdt foredrag om dansk biblioteksvæsen for at vejlede studiekredsene med hensyn til boglån.

I 1920 holdtes to lignende kurser, et på Kærehave ved Ringsted og et på Vestbirk Højskole med henholdsvis 50 og 40 deltagere. Begge kurser blev ledet af Steenberg, og som lærere medvirkede de samme som året før. På Kærehave talte lederen af Arbetarnes Bildningsförbund 
i Sverige, fil. kand.Yngve Hugo om det svenske folkedannelsesarbejde, der i flere henseender var forbillede for den danske bevægelse.

Disse kurser blev en succes og kom til at betyde meget for arbejdet ude på det lokale plan, og denne kursusvirksomhed blev fulgt op det følgende år.

Der blev også holdt lokale instruktionskurser, ligesom foreningens formand, sekretæren og forretningsføreren (Skjoldbo) rejste land og rige rundt og holdt foredrag, alene i foreningens tre første år $59 \mathrm{i}$ alt $\mathrm{i}$ højskoler, foreninger og aftenskoler. Rejseudgifterne i forbindelse hermed afholdtes undertiden af de pågaldende institutioner, men ofte af Studiekredsforeningen.

For at give indtryk af dette agitationsarbejde gengives her en imponerende tour de force, foretaget af sekretær A. Thyregaard i 1920 i Jylland og på Fyn:

"I Oktober Maaned har han talt følgende steder:

Den 5.: $\quad$ Arbejdernes Aftenskole i Skive,

Den 6.: Venstres Ungdom i Hvidbjerg,

Den 10.: Forsamlingshuset i Skjørring,

Den 11.: Forsamlingshuset i Herskind,

Den 12.: Forsamlingshuset i Mundelstrup,

Den 18.: Arbejdernes Aftenskole i Vejle,

Den 19.: Venstres Ungdom i Kappendrup,

Den 20.: $\quad$ I.O.G.T. i Odense,

Den 21:: Arbejdernes Aftenskole i Randers,

Den 24.: De samvirkende Afholdsselskaber i Aalborg,

Den 25. - 26.: Biblioteket i Vilslev, og

Den 27.: $\quad$ Afholdsforeningen i Esbjerg."

Man forstår godt, at dette ledsages med ordene: "Der er i Aar langt mere Fart i Studiekredsarbejdet end sidste Aar." ${ }^{17}$

Agitationsarbejdet har måske været særlig intensivt omkring oktober måned, hvor meget af vinterens studiekredsarbejde skulle sæettes i gang. Men det er nok også kendetegnende for studiekredsbevægelsens pionerer, at de ikke har været bange for gentagelsens monotoni på tryk som i tale. I den gode sags tjeneste kunne tingene ikke siges for tit. 


\section{Udstillingsvirksomhed}

Fra 1923 tog foreningen et nyt slagkraftigt agitationsmiddel i brug, nemlig bog- eller studieudstillinger, som viste sig velegnede til at vække interesse for studiekredse, selvstudium og planmæssig benyttelse af bibliotekerne.

Der afholdtes i 1923-24 fire udstillinger i København, Rønne, Ărhus og Holbæk. De blev tilsammen besøgt af ca. 10.000 mennesker. I forbindelse med udstillingerne holdtes der foredrag om biblioteker, bøger og studiekredse. Den første udstilling, som blev arrangeret ved et samarbejde mellem den nystiftede Københavns Studiekredsforening og Københavns Kommunebiblioteker, fandt sted 16.-26. september 1923 i det kommunale hovedbibliotek Nikolaj Kirkes læsesal. Udstillingen åbnedes af Københavns stadsbibliotekar Jens Aarsbo, som udtalte sin glæde over samarbejdet mellem bibliotekerne og studiekredsene.

Udstillingens kerne var de indtil da udkomne 40 studievejledninger med dertil hørende bogsæt, en omfattende samling som "viste, at Københavns Kommunebiblioteker ubestridt staar som de mest ydedygtige. [...] Intet andet Bibliotek i Danmark kan gøre Udstillingen saa komplet, som den var her."

Af interesse var også de udstillede grundbøger, håndbøger for hjemmet og litteratur om studiekredsarbejde og læsning, heraf især Studiekredsforeningens publikationer Folkeoplysning gennem Samlæsning og Selvstudium, Studiehaandbogen og tidsskriftet Lasning. Som forbillede til efterfølgelse eller oversættelse var vist en samling svenske grundbøger i serien Natur og kultur - danske grundbøger var en mangelvare. Den svenske litteratur om studiekredse samt de svenske tidsskrifter Bokstugan, Studiekamraten og A.B.F. var også med.

I udstillingen blev vist eksempler på nyttige håndbogssamlinger til lærerens egen boghylde. Folkeuniversitetsforeningen udstillede sine 'grundrids' (boglister udarbejdede til foreningens foredrag) og andet oplysende materiale om sin virksomhed. Kommunebibliotekerne fremlagde kataloger, beretninger, tavler og en biblioteksfører, som uddeltes gratis.

Studiekredsforeningen havde udarbejdet nogle grafiske tavler, som illustrerede statstilskuddene til bibliotekerne i Danmark, Norge og Sverige; udviklingen af den svenske studiekredsbevægelse; antallet af bøger 
i Danmarks forskellige biblioteker og udlånet af bøger fra de offentlige biblioteker uden for København.

I forbindelse med udstillingen afholdtes der hver aften foredrag om emner af interesse for oplysningsarbejdet. To aftener i løbet af udstillingsperioden blev der givet praktisk demonstration af en studiekreds i funktion.

Udstillingen blev så godt besøgt, at den blev forlænget med fire dage. Da den sluttede, havde den haft ca. 3500 besøgende, og også foredragene havde godt fremmøde. ${ }^{18}$

Denne udstilling blev et forbilledligt eksempel på samarbejde mellem mange organisationer, som alle havde folkeoplysning som formål; et samarbejde som bl.a. Steenberg mange gange efterlyste på dansk grund, mens han fremhævede Sveriges resultater på dette område.

Et par måneder senere, 25.-30. november, fandt en lignende udstilling sted i Rønne i samarbejde med den lokale biblioteksforening. Statsbiblioteket i Ărhus stillede bøger til rådighed, og der var foredrag hver aften. Ganske vist blev besøget noget mindre end ventet, men bibliotekaren i Rønne, E. Bremerstent, vurderede alligevel udstillingen som anbefalelsesværdig: "den skal nok bidrage til at bryde Isen for Studiekredssagen, hvor den kommer."

I Holbæk arrangeredes udstillingen i februar 1924 i et samarbejde mellem Danmarks Studiekredsforening, som foreningen nu kaldte sig, og en række lokale organisationer. Foreningens vandreudstilling blev suppleret med lokalt stof udstillet af bl.a. Historisk Samfund, og der var indrettet en børnelæsestue i et tilstødende lokale. Steenberg holdt foredrag om studiekredse, og Skjoldbo ledede en studiekreds i funktion. Udstillingen fik udførlig presseomtale og blev besøgt af 2000 mennesker.

Foreningen gjorde så gode erfaringer med denne vandreudstilling, at den blev ajourført og brugt i agitationsøjemed rundt omkring i landet de følgende år.

\section{Samarbejdet med bibliotekerne}

Som nævnt understreger Studiekredsforeningens ledende mænd fra forste færd den åbenlyse forbindelse mellem studiekredse og bibliote- 
ker. Kuriøst nok har man ganske vist glemt at medtage dette forhold i foreningens første love, hvor bibliotekerne ikke er nævnt med ét ord, men i praksis arbejder man på at etablere samarbejde på mange områder, selvfølgelig også fordi der er meget høj grad af personsammenfald. Det er den samme, ret lille personkreds, som er aktiv i både studiekredsbevægelsen og biblioteksbevægelsen.

I Studiehaandbogen skriver Døssing i kapitlet Studiekredsene og Bibliotekerne: "Det er ikke let paa det nuværende Tidspunkt at give almengyldige Regler for Studiekredsenes Forhold til Bibliotekerne. Studiekredsarbejdet er her i Landet endnu i sin Begyndelse og har ikke hidtil stillet store Krav til Bibliotekerne. Paa den anden Side er vort offentlige Biblioteksvæsen endnu ikke tilstrækkeligt organiseret til at kunne imødekomme specielle Krav i saa stor Udstrækning, som det vil blive nødvendigt, hvis Studiekredsbevægelsen tager Fart."

Han understreger, at en studiekreds ikke kan undvære et bibliotek, men at kredsen ikke selv bør samle bøger, således som man kender det fra Sverige, hvor studiecirklerne danner deres egne biblioteker med meget store statstilskud. En sådan udvikling er man stort set enige om at undgå herhjemme, da den medfører en splittelse af de i forvejen sparsomme ressourcer, som langt hellere bør koncentreres om udbygningen af det offentlige biblioteksvæen. Selv om Sverige i mange henseender er forbilledet for studiekredsbevægelsen, er her et træk, som man absolut ikke vil efterligne.

Døssing skitserer videre i sin artikel, hvad bibliotekerne kan eller bør kunne yde studiekredsene, og hvorledes disse, ved at fremsætte deres behov, kan inspirere bibliotekerne i deres bogvalg og i oprettelse af læsestuer med håndbøger, hvilket på denne tid endnu var et særsyn i flertallet af biblioteker på landet. Han opfordrer studiekredse udgået fra formålsbestemte organisationer til at yde biblioteket et fast årligt bidrag og derved supplere bibliotekets statstilskud.

En studiekreds bør altså henvende sig til det lokale folkebibliotek. Hvis dette ikke har de ønskede bøger, må det overveje, om de bør anskaffes, og ellers skaffe dem fra det nærmeste centralbibliotek eller gå til Statsbiblioteket i Ârhus, som har den specielle opgave at virke for det almene oplysningsarbejde over hele landet ved gratis udlån af oplysende litteratur, evt. portofrit udsendt. ${ }^{19}$ 
Døssing havde været klartskuende. I løbet af få år fik studiekredsbevægelsen så meget vind $\mathrm{i}$ sejlene, at dens krav til bibliotekerne var ved at vokse disse over hovedet, skønt biblioteksvæsenet også havde været inde $\mathrm{i}$ en vældig vækst $\mathrm{i}$ samme periode. Spørgsmålet om, hvorledes man skaffer bøgerne til studiekredsene, behandles allerede i Lasnings første årgang (1922) i 6-7 indlæg.

\section{Statsbiblioteket}

Emanuel Sejr redegør kort for Statsbibliotekets rolle. Om studiekredssagen siger han: "Det er i høj Grad ønskeligt, at dette systematiske Arbejde, som endnu virker famlende og usikkert, maa vokse sig stærkt og bevidst." Han understreger, at Statsbiblioteket vil have supplerende funktion, hvad angår forsyning af dansk faglitteratur. Lånevejen bør først gå til det lokale bibliotek, derfra til centralbibliotekerne, hvoraf nogle har anskaffet sig studiekasser til de mest efterspurgte emner. Slår det heller ikke til, træder Statsbiblioteket til. Med hensyn til udenlandsk litteratur træder Statsbiblioteket i første række. Grundbogen bør hver deltager selv eje.

\section{Centralbibliotekerne}

I indlæg om centralbibliotekerne foreslår både $\mathrm{H}$. Hvenegaard Lassen og Carl Thomsen, at bibliotekerne må organisere deres indkøb af Emnekasser med bøger om de mest dyrkede emner. Ifølge Hvenegaard Lassen står centralbibliotekerne allerede $\mathrm{i}$ tæt forbindelse med studiekredsene, som han anser som en "naturlig Forbundsfælle" for bibliotekerne. Centralbibliotekerne har ofte givet impuls til dannelse af studiekredse, de har udarbejdet læseplaner, og mange biblioteksfolk er aktive studieledere. Det er hans overbevisning, at kommende centralbiblioteksbygninger vil indeholde lokaler til studiekredsene, således at sammenknytningen vil blive frugtbringende for begge parter.

Studiekredsforeningens arbejdsudvalg udkastede en plan til, hvorledes de studiekasser/emnekasser, som nogle centralbiblioteker havde anskaffet, kunne udnyttes optimalt. Man påtænkte at oprette en "intercentral" organisation, således at det enkelte centralbibliotek kunne låne studiekasser hos de andre. Studiekredsforeningen skulle fungere som bindeled, idet centralbibliotekerne skulle meddele sekretæren, hvilke 
studiekasser de havde, og til ham kunne studiekredse henvende sig om udlån af de ønskede kasser.

Steenberg forelagde planen for centralbibliotekarerne ved Danmarks Biblioteksforenings årsmøde i 1922, og planen vandt udelt tilslutning hos de tilstedeværende. Man blev enige om også at søge at inddrage Statsbiblioteket i ordningen.

Steenberg sendte en fremstilling af planen ud til de dengang 13 centralbiblioteker sammen med en forespørgsel om deres holdning til sagen. De blev spurgt, (a) om de havde studiekasser, (b) om de ville lade disse indgå $\mathrm{i}$ en intercentral udlånsordning med andre centralbiblioteker, og (c) om de ville holde Studiekredsforeningens sekretær informeret om, hvilke studiekasser de eventelt kunne udlåne. Svarene fordelte sig i tre grupper:

(1) Nykøbing F., Svendborg, Silkeborg og Esbjerg har studiekasser og vil tiltræde ordningen.

(2) Næstved, Rønne, Vejle, Viborg, Lemvig og Hjørring vil arbejde for at oprette studiekasser og derpå gå med i ordningen.

(3) Holbæk, Ăbenrå og Ălborg har ingen studiekasser, men hvis de fâr, vil de nok tiltræde ordningen.

Studiekredscentral og studiekredshøjskole?

Carl Thomsen gør sig i sit indlæg "Hvorledes skaffer vi Bøgerne?" overvejelser om at samle alle studiekasserne på et sted, f.eks. i Statsbiblioteket, hvilket vil være det teknisk enkleste, men måske ikke den mest rationelle udnyttelse, da bøgerne så ikke kan bruges af de almindelige lånere uden for studiekredsene. I Esbjerg Centralbibliotek, hvor Carl Thomsen er bibliotekar, er man nået et skridt videre, idet man har organiseret anskaffelsen af studiekasser og udlåner dem gratis til studiekredse, primært i det lokale biblioteks område, dernæst til andre lokalbiblioteker i centralbiblioteksområdet.

Carl Thomsens idé om at samle studiekasserne er et af flere tilløb til dannelse af en studiekredscentral. I en situationsberetning om studiekredsarbejdet på Bornholm i februar 1923 fremsætter den derværende bibliotekar E. Bremerstent forslag om, at Studiekredsforeningen skal oprette en studiekredshøjskole til uddannelse af ledere og et studiekredsbibliotek for hele landet. 
Ved disse foranstaltninger ville man yderligere opnå et par sidegevinster. Det ville styrke tilgangen af medlemmer, idet "alle der har været paa Studiekredshøjskole, og alle Kredse, der havde faaet Bøger fra Studiekredsbiblioteket, vilde være knyttet til Foreningen ved en reel Forbindelse med det saa nødvendige materielle Bindeled." [...] "Endelig - sidst, men maaske vigtigst - vilde vort Studiekredsarbejde faa en neutral Grund at mødes paa. [...] Man vil jo sikkert være enig om, at de forhaandenværende Partiorganisationer, faglige, politiske o.s.v., er det naturlige Moderskød for Studiekredse. Her findes alle de Betingelser, som skal til for at faa Studiekredse til Verden. Men dette Forhold har sikkert sin svage Side i Partiskheden. Den kunde blive modvirket paa Studiekredshøjskolen og ved det fælles Bibliotek. Og endelig kunde det maaske hindre, at vi fik den Udvikling, som Sverige har faaet, hvor Studiekredsene faar Statstilskud til de Bøger, de køber, og saaledes opretter en Mængde smaa Biblioteker rundt om og spreder de i Forvejen ikke alt for stærke Kræfter."

Det er et klart forsøg på - på et meget tidligt tidspunkt i bevægelsens udvikling - at modvirke en politisering af studiekredsarbejdet.

\section{Kobenhavns Kommunebiblioteker}

I Københavns kommune kom samarbejdet mellem bibliotekerne og studiekredsbevægelsen til at sætte mange spor, navnlig efter dannelsen af Københavns Studiekredsforening (lokalafdeling af Danmarks Studiekredsforening). Det manifesterede sig allerede ved den omtalte første studiematerialeudstilling i Nikolaj Kirke i efteråret 1923 og ved en senere udstilling i 1926.

Under den initiativrige stadsbibliotekar Jens Aarbos ledelse, støttede Københavns Kommunebiblioteker (KKB) studiekredsene ved favorable udlånsvilkår - udlån af flere bøger og for et længere tidsrum end normalt fastsat - ved udstedelse af studiekort og ved at stille lokaler til rådighed for studiekredsene, så vidt det overhovedet var muligt for bibliotekerne inden for deres beskedne rammer. Aarsbo ivrede stærkt for at få indrettet studiekredslokaler ved planlægningen af nye biblioteksbygninger. KKB abonnerede på et stort antal eksemplarer af Lasning, og i samtlige kredsbiblioteker fandtes komplette sæt af Studiekredsforeningens vejledninger og småskrifter. 
Studiekredsforeningens sekretær C. L. Skjoldbo vurderer KKB's indsats således: "Denne store Støtte fra Københavns Kommunebibliotekers Side har sikkert bidraget stærkt til, at Studiekredsarbejdet netop i København har taget et saa stærkt Opsving, som Tilfældet har været, og der er al Grund til at paaskønne denne Hjælp, som vistnok er uden Sidestykke her i Landet." ${ }^{20}$

\section{Indsamling af statistisk materiale om studiekredsvirksomheden}

For at kunne vejlede centralbibliotekerne ved indkøb og tilrettelæggelse af studiekasser og for at løse den store opgave med bogforsyningen $\mathrm{i}$ det hele taget, forsøgte Studiekredsforeningen at skaffe oplysninger om studiekredsenes antal og emner.

Dette var en meget vanskelig opgave for foreningen, som kun i ringe omfang selv dannede studiekredse og derfor ikke stod i direkte organisatorisk forbindelse med studiekredsene rundt i landet. Foreningen arbejdede med at vejlede de kredse, der måtte opstå inden for andre foreninger og organisationer eller blandt private. Af sådanne organisationer, der især arbejdede i studiekredse, kan nævnes Danmarks socialdemokratiske Ungdom, Venstres Ungdom, Studentersamfundet, Arbejdernes Læseselskab, arbejderhøjskolerne, højskoler og forskellige afholdsorganisationer.

Ved at udsende spørgeskemaer til en række biblioteker og organisationer lykkedes det at tilvejebringe et sparsomt og usikkert statistisk materiale om studiekredsarbejdet i 1923-24. ${ }^{21}$

På grundlag af det indkomne materiale kunne man opstille en statistik over emner og emnefordeling for $\mathrm{i}$ alt $71 \mathrm{kredse}$. Dertil kom ca. 35 kredse inden for Danmarks socialdemokratiske Ungdom og ca. 30 kredse inden for Venstres Ungdom, hvis emner ikke er oplyst. Det formodes, at der desuden har været en del kredse i gang uden tilknytning til biblioteker eller organisationer.

1923-24: Det anslås, at der i vinteren 1923-24 i alt har været ca. 150 kredse i gang.

1924-25: For vinteren 1924-25 har man oplysning om emnefordeling for 188 kredse samt kendskab til ca. 100 kredse, som hovedsageligt har arbejdet med sociale emner, der ikke er nøjagtigt 
oplyst. Den store stigning i antallet af kredse må primært tillægges oprettelsen af Arbejdernes Oplysningsforbund (AOF) i 1924.

1925-26: Oplysninger indsamlet for 1925-26 lader formode, at der har været ca. 400 studiekredse i funktion, heraf de 256 i AOF's regi. Emnefordelingen er oplyst for 84 kredse. I AOF's årsberetninger $1925 \mathrm{ff}$ er forbundets studiekredsvirksomhed beskrevet med nøjagtige oplysninger om emner, antal kredse samt kredsenes emnemæssige og geografiske fordeling.

1926-27: Gennem bibliotekerne har Studiekredsforeningen for vinteren 1926-27 fẩet oplysning om 147 studiekredse og deres emnefordeling. Foreningen anslår, at der $\mathrm{i}$ alt har været ca. 450 studiekredse i gang. Det understreges kraftigt i Studiekredsforeningens årsberetning, at det statistiske materiale, man har indsamlet, kun kan bruges som "en betinget Maalestok", bl.a. fordi det vides, at mange studiekredse arbejder uden støtte fra bibliotekerne.

1927-28: Foreningen har for dette år kun samlet oplysninger om studiekredsene fra de enkelte institutioner, da man har måttet erkende, at de hidtidige forsøg på at opstille en statistik, bl.a. via bibliotekerne, er behæftet med store svagheder. Det anslås, at der i vinteren 1927-28 har været ca. 500 studiekredse i arbejde.

Foreningen kan blot konkludere, at der år for år har været en støt fremgang for studiekredsvirksomheden, uden at man kan opstille sikre tal. Dette blev en alvorlig hæmsko for arbejdet med at løse bogforsyningsproblemet.

Samarbejde med ovrige folkeoplysende organisationer

Inspireret af højskolebevægelsen havde der ud over landet bredt sig talrige foredragsforeninger med en frodig, men planløs foredragsvirksomhed, hvis oplysningsværdi man blandt ledende folkeoplysningsfolk i stigende grad satte spørgsmålstegn ved.

En undtagelse udgjorde Folkeuniversitetsforeningernes foredragsvirksomhed, som havde en organiseret plan med foredrag holdt i ræk- 
ker med et til hver foredragsrække trykt grundrids med litteraturhenvisninger. Foredragene suppleredes med spørgetimer. Til gengæld lå dette arbejde på et så højt niveau, at det næppe kunne kaldes folkeoplysning i bred forstand.

En af Steenbergs kongstanker var at etablere en sammenhæng mellem den traditionelle foredragsvirksomhed, læsning og arbejde i studiekredse. Foredraget skulle vække interessen for et emne, det nærmere kendskab til emnet fâs gennem bøger, og endelig kunne emnet uddybes ved arbejde i studiekreds. Fordelen ved en organisatorisk forbindelse mellem foredragsforening, folkebibliotek og studiekreds var indlysende. Alligevel lykkedes dette samarbejde kun sporadisk. Forskellige foredragsforeninger indbød ganske vist Studiekredsforeningens formand og sekretær til at holde foredrag om studiekredsarbejde, men i en artikel i Lasning 1927 måtte Steenberg konkludere, at de foredragsforeninger, der har sluttet sig op om folkehøjskolernes arbejde, kun i ringe omfang har søgt samarbejde med Studiekredsforeningen.

En sikker måde at fremme studiekredsarbejdet på ville være, om man tog dette arbejde op på højskolerne. Hvis eleverne her blev fortrolige med denne arbejdsform, ville de, når de forlod højskolen, drage ud i deres lokalsamfund med interesse for at oprette og lede studiekredse her.

Lasnings redaktion henvendte sig til højskolerne og opfordrede dem til at skrive til bladet om deres eventuelle erfaringer med studiekredse. ${ }^{22}$ En del højskoler har taget arbejdet op, bl.a. Rødding, Askov, Arbejderhøjskolen i Esbjerg og Den internationale Højskole i Helsingør, men der tegner sig en generationskløft mellem de gamle højskolefolk, som stadig sværger til 'det levende ord', og den nye generation af højskolelærere, som mener, at vækkelse ved foredrag skal følges af vækst ved læsning.

\section{Samarbejde med folkeoplysningsarbejde $i$ udlandet}

Studiekredsforeningen var som nævnt fra sin start inspireret af oplysningsarbejdet $\mathrm{i}$ udlandet, og $\mathrm{i}$ hele sin virketid havde foreningen mange kontakter dertil, især til Sverige. Læsning bringer mange indlæg om, "hvad vi kan lære af Sverige". Steenberg har tæet personlig kontakt til de ledende folk i ABF og IOGT, og ved møder og instruktionskurser i 
både Danmark og Sverige er der hyppig deltagelse fra nabolandet. På talrige ledder har kontakten til Sverige været en uvurderlig inspirationskilde for studiekredsbevægelsen i Danmark.

Lasnings spalter gav også plads for udblik til et særligt oplysningsarbejde i Tyskland, nemlig oplæsningstimer ved bibliotekerne. Dette praktiseredes ved Stadtbibliothek Stettin under Erwin Ackerknechts auspicier og skildres i to indlæg i 1923 og i 1926. Ackerknecht udgav en bog med i alt 99 programmer for oplæsningsmøder. I korthed går en oplæsningstime ud på højtlæsning af kortere og længere stykker skønlitteratur samlet omkring et bestemt emne. For at sikre højtlæsningens 'dannelsesvirkning', udarbejdede biblioteket en liste over de bøger, som højtlæsningen måtte have vakt interesse for, ikke kun de værker der var læst højt af, men også f.eks. biografiske eller kulturhistoriske værker med tilknytning til emnet. Steenberg mente, at denne arbejdsform udmærket kunne være en naturlig indfaldsvinkel til arbejdet $\mathrm{i}$ en studiekreds.

I Studiekredsforeningens udveksling af. erfaringer med oplysningsorganisationer i andre lande indtog Steenberg en nøgleposition, idet han gennem sit mangeårige virke som utrættelig agitator for folkebibliotekssagen havde knyttet mange personlige forbindelser til fremtrædende repræsentanter for folkeoplysning i udlandet, som han nu også i sin egenskab af.formand for Studiekredsforeningen kunne drage nytte af.

\section{Studiekredsforeningens ophor}

I 1927 gør Steenberg i optimistisk jubilæumsstemning rede for Studiekredsforeningens aktiviteter gennem ti år og konkluderer således: "Saa meget kan siges med Sikkerhed, at vor Forening har fremmet Studiekredsarbejdet meget betydeligt i de 10 Aar, i hvilke den har virket. Arbejdet har ikke været let, da den maatte arbejde i en Befolkning, hvoraf en Del saa med Ligegyldighed, undertiden endog med en vis Modstand, paa det trykte Ord. [...] Naar der nu i 1918 blev taget fat igen, og Heldet denne Gang har fulgt Arbejdet, saa skyldes dette ikke blot, at Folkets Læsning er bleven stærkt forøget gennem Folkebibliotekernes Udvikling, men ogsaa, at denne Læsning gennem Bibliotekernes Arbejde til Dels har skiftet Karakter. Bogen søges nu ikke blot for gen- 
nem den at faa en god Hjælp til at udfylde en ledig Stund; men det er blevet mere almindeligt forstaaet, at Bogen kan være et godt Arbejdsredskab, der kan hjælpe ved det daglige Arbejde for Brødet. Vor Forening staar derfor i stor Gæld til det Arbejde, som gennem Biblioteksbevægelsen er sket for at forøge og forbedre det danske folks Brug af Bøger. Og Folket er gennem Foreningens Arbejde vundet fremad, ogsaa hvad Selvstudiet angaar, fordi Studiekredsarbejdet gaar ud paa at fremme den Enkeltes evne til at kunne bruge en Bog.

Ved Siden heraf har Foreningen fremmet den Følelse af Samhørighed, som præger vor Tid og derigennem fremhjælper en lykkelig Demokratisering.

Vi, som arbejder for Studiekredsbevægelsen, ser med Fortrøstning paa dens Fremtid. Den hænger nøje sammen med Udviklingen af Bibliotekerne og med Udviklingen af Samhørighedsfølelsen. Derfor vil Fremgangen i Studiekredsarbejdet være sikret." ${ }^{23}$

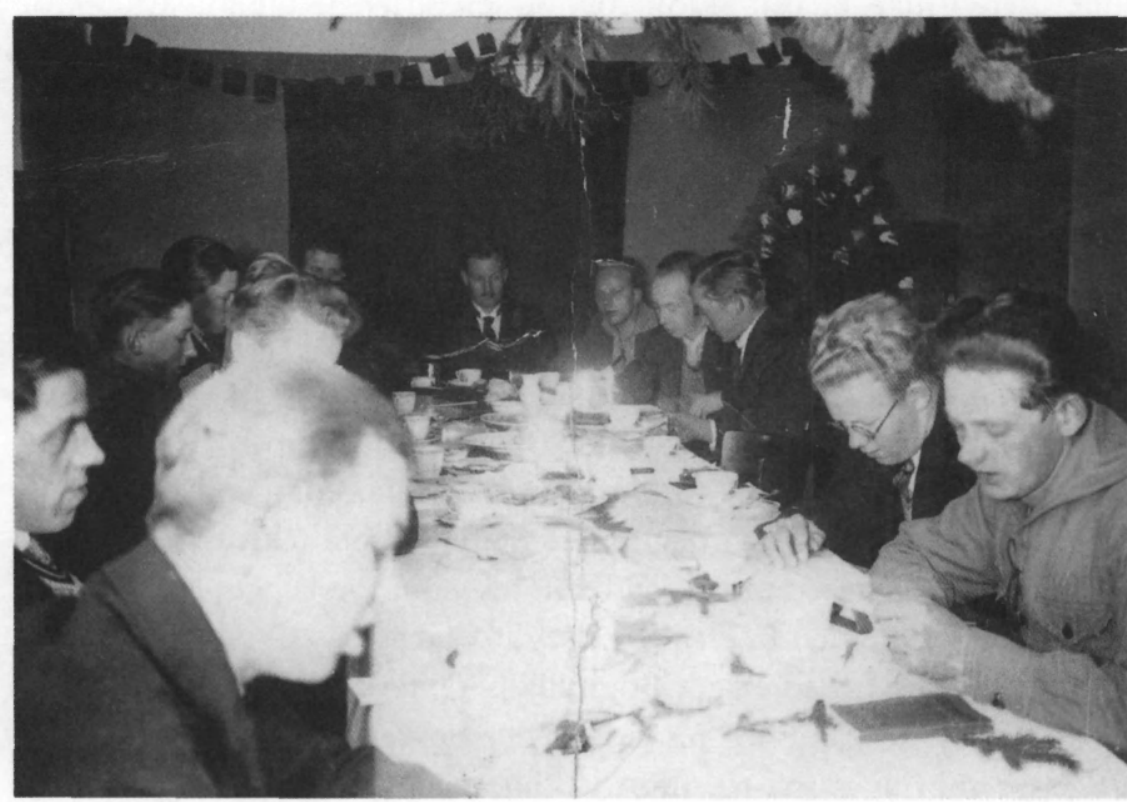

Forbindelsen med bibliotekerne og studiekredsaktiviteten fortsatte efter Studiekredsforeningens ophor Fotografi fra Arbejdernes Oplysningsforbund i Lyngby med teksten: Studiekreds i samfundsøkonomi 1931-1932. Leder bibliotekar Møballe. Arbejderbevagelsens Bibliotek og Arkiv 
Den 8. januar 1928 fejrede foreningen sit tiårs jubilæum. Ved jubilæumsmødet i København deltog repræsentanter for det frie folkeoplysningsarbejde i Danmark og Sverige. På mødet blev givet en række oversigter over studiekredsbevægelsens arbejde i begge lande, og man drøftede fremtidige arbejdsopgaver for Studiekredsforeningen. Jubilæet gav anledning til en del presseomtale af foreningen og dens arbejde.

Der var intet i jubilæumsfestlighederne, som tydede på, at foreningen stod over for sin snarlige opløsning. Det forekommer derfor ganske overraskende, at der allerede 3-4 måneder senere, på foreningens årsmøde den 26. april 1928, af bibliotekar E. Bremerstent fremsættes forslag om, "at Danmarks Studiekredsforening standser sin hidtidige Virksomhed og ophæves fra April 1929." Foreningen ville imidlertid fầ sin død i skønhed, da det var Bremerstents hensigt at ansøge undervisningsministeriet om at fă foreningens statstilskud $(1.900 \mathrm{kr})$ overført til oprettelse af et studiekredsbibliotek. Et sådant havde som nævnt været foreslået af Bremerstent allerede i 1923, ${ }^{24}$ og tanken havde siden været luftet flere gange, bl.a. af Skjoldbo, ${ }^{25}$ og senest havde biblioteksdirektør Th. Døssing på Studiekredsforeningens jubilæumsmøde slået til lyd for idéens gennemførelse. ${ }^{26}$

Mødedeltagerne var enige om, at foreningen havde løst sin hovedopgave, nemlig at gøre studiekredsen som arbejdsform kendt. Man enedes også om, at det næste store mål måtte være oprettelse af et studiekredsbibliotek til afhjælpning af det presserende bogforsyningsproblem. Forsamlingen vedtog derfor følgende resolution: "Danmarks Studiekredsforening ansøger Ministeriet om, at det Statstilskud, Foreningen hidtil har faaet, overføres til Statens Bibliotekstilsyn med det Formaal deraf at danne et Bibliotek for Studiekredsene. Foreningen henstiller til Ministeriet, at den i Samarbejde med Statens Bibliotekstilsyn udarbejder en Plan for dette Studiekredsbibliotek, som forelægges Ministeriet. Grundtrækkene i denne Plan foreslaas at være:

Bibliotekstilsynet foretager Bogindkøbet efter Samraad med Repræsentanter for de Landsorganisationer, der ønsker at bruge Biblioteket. Bøgerne anbringes paa et eller to Biblioteker efter Tilsynets Skøn og udlaanes efter nærmere fastsatte Regler. Tilsynet sammenkalder een Gang aarlig Repræsentanter til et Møde, hvor Spørgsmaal vedrørende Biblioteket drøftes." ${ }^{27}$ 
Man besluttede at nedlægge foreningen pr. 31. marts 1929 og at lade Lasning udgå pr. 31. december 1928. Der var nok tale om, at man med de ovennævnte smukke intentioner gjorde en dyd af en økonomisk nødvendighed. Under indtryk af tidernes almindelige ugunst, som havde medført nedskæringer på så at sige alle sociale og kulturelle områder, var foreningens statstilskud blevet drastisk beskåret, således at det inden for de snævre økonomiske rammer næppe var muligt at opretholde endsige udvide foreningens aktiviteter.

Fra finansåret 1919-20 havde foreningen fâet bevilget en årlig statsunderstøttelse på $3.000 \mathrm{kr}$., hvilket var så langt den vigtigste af foreningens indtægter. For 1925-26 og 1926-27 nedsattes tilskuddet til 2.700 kr. og det blev i 1927-28 yderligere beskåret til 1.900 kr. Også foreningens øvrige indtægter, kontingenter og legater, faldt i dette år, således at regnskabet for 1927-28 balancerede med 3.528,75 kr., medens det i tidligere år havde balanceret på omkring $5.000 \mathrm{kr}$. At foreningen havde færre midler at virke med, gik ud over virksomheden, og det forårsagede en nedgang i medlemstallet. ${ }^{28}$

I "Et Afskedsord til Læserne" giver en af foreningens ledende mænd C.L. Skjoldbo, kasserer og ansvarshavende redaktør for Lasning (med Steenberg som medredaktør) sin vurdering af foreningens ophør. I modsætning til andre foreninger som opløses, og blade som går ind på grund af manglende interesse, så ophører Studiekredsforeningen og Lasning på grund af succes. Studiekredssagen har nu vokset sig så stærk, at den kan klare sig selv. "Den Støttestav, som navnlig "Læsning" har været for Studiekredsbevægelsen, kan Bevægelsen nu undvære, og intet vilde være mere forkert end at gaa med Stok længere end nødvendigt. Hertil kommer det meget væentlige Moment, at andre og langt stærkere Organisationer har taget Sagen i deres Haand og ført den videre, først og fremmest Arbejdernes Oplysningsforbund, som netop har indset Studiekredstankens Vigtighed, specielt for Arbejderne." Skjoldbo mener optimistisk, at bibliotekerne vil være behjælpelige med at dække det behov for studievejledninger om almindelige oplysende emner, som nu ikke mere kan opfyldes gennem foreningen. ${ }^{29}$

For Skjoldbo synes foreningens opløsning således en ganske naturlig og uproblematisk sag. Der kunne dog nok have været grund til at be- 
klage, at studiekredsbevægelsen mistede et neutralt/alment centralorgan, som dels kunne virke for de mange, som ikke var medlem i nogen af de faglige og politiske organisationer, som nu havde taget arbejdet op, dels kunne have haft konsultativ og koordinerende betydning for de nævnte organisationer.

Beklageligt var det også, fordi den tætte forbindelse, der havde været mellem studiekredsbevægelsen og biblioteksbevægelsen i nogen grad opløstes med foreningen. Fra Studiekredsforeningens start havde mange fremtrædende biblioteksfolk siddet $\mathrm{i}$ foreningens bestyrelse og arbejdsudvalg, og man havde anset samarbejdet for gensidigt stimulerende.

Og beklageligt ikke mindst, fordi der under indtryk af den økonomiske krise skulle hengå et helt årti, før det lykkedes at få oprettet det studiekredsbibliotek - Studiekredscentralen - som Studiekredsforeningen havde tilstræbt at lægge grunden til ved overførsel af sit statstilskud.

Vel nåede foreningen ikke op på synderligt store medlemstal, ${ }^{30}$ men den solgte også sine vejledninger til ikke-medlemmer. Trods sine beskedne økonomiske rammer blev det foreningens fortjeneste at gøre studiekredsen som arbejdsform kendt og gennem et stort og uegennyttigt arbejde at skabe et udmærket fundament, som andre organisationer kunne bygge videre på.

Andre organisationer, som tog studiekredsarbejdet op Lige fra Studiekredsforeningens start blev dens virksomhed fulgt med interesse fra andre organisationers side, især vakte arbejdet opmærksomhed i politiske organisationer. Fra begyndelsen af 1920'erne gik organisationen af studiekredsbevægelsen $i$ to retninger:

For det første var der den centrale forening, Studiekredsforeningen, fra 1923 benævnt Danmarks Studiekredsforening, med lokale afdelinger i de store byer København, Ărhus og Esbjerg, som dels arbejdede for at udbrede kendskab til studiekredsen som arbejdsform, dels bistod allerede eksisterende studiekredse, især gennem tidsskriftet Lasning.

Den anden retning var repræsenteret ved forskellige landsorganisationer med tilknytning til politiske partier, som tog dannelsen af studiekredse op som led i deres oplysningsarbejde. Der findes næppe en ungdomsorganisation, som ikke i løbet af 20 -erne og 30 -erne tog stu- 
diekredsarbejde på deres program. Her kan blot nævnes VU, Landsorganisationen Venstres Ungdom, den største af de politiske ungdomsorganisationer, der som den første organiserede sit studiekredsarbejde, og AOF, Arbejdernes Oplysningsforbund, den landsorganisation, der siden oprettelsen i 1924 fik den allerstørste betydning for folkeoplysningen i almindelighed og studiekredsarbejdet i særdeleshed

Intet under, at studiekredsarbejdet har haft så stærk appel til især de politiske organisationer. Gennem hele sin arbejdsform er studiekredsen netop en skoling i demokrati og organisation. Den er deltagerstyret og deltageraktiverende, den giver deltagerne øvelse $\mathrm{i}$ at formulere sig mundtligt og skriftligt og lærer dem gennem diskussioner at argumentere for sine synspunkter - alt sammen færdigheder, som er vigtige for deltagelse i det politiske liv eller i organisationsarbejde.

\section{NOTER}

1. Bogsamlingsbladet, 1914 (nr. 7) s. 82.

2. A.S. Steenberg: Folkebogsamlinger, deres Historie og Indretning. 1900, s. 6-8.

3. Bogsamlingsbladet, 1911 (nr. 1) s. 11.

4. Bogsamlingsbladet, $1911 \mathrm{nr}$. 3-4, 5-6.

5. Bogsamlingsbladet, 1915 (nr. 12) s. 213-216

6. Vore Folkebogsamlinger. Deres Nytte og Nødvendighed. 1915, p.56f.

7. Læsning, 1927 (nr. 7) s. 98: Danmarks Studiekredsforening. De første 10 Aar.

8. Bogens Verden, 1918-19, s. 1.

9. Bogens Verden, 1918-19, s. 33.

10. Bogens Verden, 1920, p.40.

$\begin{array}{llll} & 1910-11 & & 1918-19 \\ \text { Stedlige tilskud } & \text { ca. } 35.000 \mathrm{kr} . & \text { ca. } & 200.000 \mathrm{kr} \\ \text { Statslige tilskud } & \text { ca. } 12.000 \mathrm{kr} . & \text { over } & 100.000 \mathrm{kr} .\end{array}$

11. Bogens Verden 1918-19, s. $111 \mathrm{ff}$.

12. Læsning, 1923 passim.

13. Bogens Verden, 1919-20, s. 67-68.

14. H.O. Lange i sin afskedsartikel til Steenberg. I: Bogens Verden, 1920, p. 49.

15. Læsning, 1922, s. 3.

16. Læsning, 1927 (nr. 7) s. 113-119.

17. Bogens Verden, 1919-20, s .280.

18. Læsning, 1923 (nr. 4) s. 52-57. 
19. Studiehaandbogen, 1919 , s. 84-91.

20. Læsning, 1927, p.112.

21. Dette statistiske materiale er publiceret i Læsning i Studiekredsforeningens årsberetning.

22. Læsning, 1928, s. 78-82.

23. Læsning, 1927, s. 105.

24. Læsning, 1923, s. 4.

25. Bogens Verden, 1925, s. 77-80.

26. Læsning, 1928, s.10.

27. Læsning, 1928, s. 74.

28. Kilder til foreningens finansiering er Regnskab for Danmarks Studiekredsforening, publiceret i hver årgang af Læsning.

29. Læsning, 1928, s. 107

30. Ifølge Læsning, 1924 , s. $155 ; 1927$, s. $63 ; 1928$, s. 60 :

1922-23: 138 betalende medlemmer

1923-24: $\quad 360$

1924-25: $\quad 401$

1925-26: $\quad 387$

1926-27: $\quad 371$

1927-28: "dalet en Del"

Som medlemmer kunne optages: personer over 16 år, samt foreninger og institutioner, der kan indmelde sig ved et eller flere medlemmer, betaler kontingent og har stemmeret og andre rettigheder i forhold hertil. Kontingentet er $4 \mathrm{kr}$. årligt. Medlemmer modtager foreningens skrifter gratis eller mod rabat. (Foreningens love, paragraf 3, ændret 1923, Læsning 1923, s. 28). 